\title{
The Relationship between Obesity, Insulin Resistance and Aldosterone Levels
}

\author{
Sarah Conchon Costa, Alexandro Marcio da Silva Mattos, Anna Catarina Gatzk de Arruda, Danielle Müller \\ Fabretti, João Gabriel Nogueira Scorpione and Tânia Longo Mazzuco* \\ Endocrine Interactions Research Group, Post-graduation Program of Health Sciences, State University of Londrina, Brazil
}

Submission: January 22, 2018; Published: March 06, 2018

*Corresponding author: Tânia Longo Mazzuco, Departamento de Clínica Médica, Centro de Ciências da Saúde da Universidade Estadual de Londrina, Av. Robert Koch, 60, Londrina, PR, Brazil, Tel/Fax: +55 43 3371-2328; Email: tmazzuco@uel.br

\begin{abstract}
The epidemic of obesity is associated with elevated risk of type 2 diabetes mellitus, hypertension, obstructive sleep apnea, coronary heart disease and stroke. Primary aldosteronism, the most prevalent etiology of endocrine hypertension, is discussed in the present review as a causeeffect relationship between aldosterone and the cardio-metabolic syndrome. Emerging findings have shown that aldosterone levels are excessive in obesity and contribute to both cardiovascular dysfunction and insulin resistance which is associated with obesity and sleep apnea. According to the updated Endocrine Society Clinical Practice Guideline, the application of aldosterone: renin ratio is now indicated to all patients with sustained blood pressure above $150 / 100 \mathrm{~mm} \mathrm{Hg}$, which could, in the future, result in the primary aldosteronism detection in a large number of patients. Within this clinical context, hypertensive patients with obesity and diabetes are candidates to be "at-risk" population in prevalence studies of aldosteronism.
\end{abstract}

Keywords: Obesity; Diabetes mellitus; Aldosteronism; Insulin resistance; Sleep apnea; Metabolic syndrome.

\section{Introduction}

Arterial hypertension prevalence is rapidly enhancing with obesity associated with insulin resistance and dyslipidemia, all components of cardiometabolic syndrome [1]. The metabolic syndrome impact on cardiovascular outcomes is well established, with high morbidity and mortality, and, for such fact, the reninangiotensin-aldosterone system on metabolic syndrome has been the target of many studies [2]. On the one hand, obesity causes arterial hypertension, and on the other hand, endocrine hypertension caused by aldosterone anomalous production is associated with metabolic syndrome development.

\section{Primary aldosteronism and hypertension}

Primary aldosteronism (PA), the most important etiology of endocrine hypertension, results from the independent renin-angiotensin system production of aldosterone [3]. It is potentially curable and the most common cause of secondary hypertension. PA has a wide range of conditions, but two major causes of primary aldosteronism are bilateral adrenal hyperplasia (BAH), accounting for $65-70 \%$ of PA patients, and aldosterone-producing adenomas (APA), accounting for 30$35 \%$ of PA [4]. Several hormone receptors have been shown to be involved in the renin-independent regulation of aldosterone secretion in PA [5]. New evidence points toward increasing metabolic dysfunction rates and vascular events in PA patients in comparison with essential primary hypertensive patients [6].

According to the updated Endocrine Society Clinical Practice Guideline, the screening of aldosterone: renin ratio is now indicated to all patients with sustained blood pressure above 150/100mmHg; resistant hypertension; hypertension and spontaneous or diuretic-induced hypokalemia; adrenal incidentaloma; hypertension and a family history of early-onset hypertension or cerebrovascular accident at a young age $(<40$ year) and all hypertensive first-degree relatives of patients with PA [3]. This could result in the primary aldosteronism detection of a large number of patients in the future [3,7]. Early diagnosis and therapy of PA (adrenalectomy or mineralocorticoid receptor antagonist) prevent its cardiovascular, metabolic, and renal morbidities. Patients will benefit from surgical or medical therapy according to a multistep approach to diagnosing and subtyping PA which includes confirmatory tests and adrenal vein sampling to differentiate lateralized from bilateral sources of PA $[8,9]$. Plasma aldosterone concentrations $>10 \mathrm{ng} / \mathrm{dL}$ in concert 
with plasma renin activity $<1 \mathrm{ng} / \mathrm{mL} / \mathrm{h}$ indicates that additional investigation should be performed [3]. In the clinical practice, hypertensionin PA responds well to specific treatmentsdirected against aldosterone excess. Therefore, it is possible that PA screening is not performed when we consider the technical difficulty in performing all stages of the investigation, including withdrawal of antihypertensive medication, saltloadingprotocols and invasive vascular examination. Thus, many hypertensive patients are treated with mineralocorticoid receptor antagonists and potassium-sparing diuretics and are not further evaluated for the diagnosis of PA.

\section{Obesity, metabolic syndrome and aldosterone}

Adipocyte production of angiotensinogen, angiotensin and aldosterone have been described, which amplify adrenal steroidogenesis [10,11]. Moreover, adipocyte-derived factors such as leptin exert a direct action on adrenal glomerulosa, increasing aldosterone synthesis [12]. The variation on aldosterone levels in obesity may challenge the accuracy of PA detection since it represents a nonlinear correlation with its plasma concentration [13].

Aldosterone levels are associated with cardiometabolic events, promoting systemic inflammation, endothelial dysfunction, vascular stiffness, hypertension, cardiac hypertrophy, and these associations are partly independent of aldosterone effects on blood pressure [3]. Also, it has been described an independent association between aldosterone and metabolic syndrome, due to impaired pancreatic $\beta$ cell function, skeletal muscle insulin sensitivity, fatty liver disease, and increased release of proinflammatory cytokines from adipose tissue $[12,14]$. As an important component of the cardiometabolic syndrome, sleep apnea is also related to obesity, diabetes, and aldosterone levels [15-17]. Obstructive sleep apnea was found in 33.9\% of hypertensive patients with PA [15] and in $85 \%$ of resistant hypertensive patients [18]. Thus, aldosterone overproduction seems to contribute to the worsening of underlying obstructive sleep apnea related to obesity and hypertension.

\section{Insulin resistance and aldosterone}

Aldosteronism can modify glucose metabolism, leading to insulin resistance, but some of the physiological pathways of mineralocorticoid effects are still discussed [11,19]. Aldosterone effects include direct action on pancreatic betacell mineralocorticoid receptors (MR), compromising their functional and structural integrity and reducing insulin release; induction of insulin resistance by the MR activation in adipose tissue; indirect effects related to hypokalemia states; and recent reported non-genomic mechanisms on various target organs such as vascular cells [2,11]. Both hyperglycemia and diabetes are more prevalent in hypertensive patients with PA than in those with essential hypertension $[20,21]$.

Elevated levels of aldosterone may also act similarly to hyperglycemia state, causing oxidative stress, reducing nitric oxide production and activating inflammatory pathways leading to vasculopathy, once again resulting in improved cardiovascular risk [22]. Aldosterone levels are directly correlated with mortality rate by cardiovascular causes in type 2 diabetes [11].

\section{Conclusion}

Aldosterone has been recognized to play an important role in the development of cardiovascular and endocrine-metabolic diseases. According to the current guidelines, clinicians should consider PA screening for most patients with hypertension. Hypertensive patients with obstructive sleep apnea, obesity and insulin resistance are groups with potentially high prevalence of PA. In addition to adrenocortical cells, adipose tissue is also able to secrete aldosterone; although somecross-talk mechanisms are not well established, the cardiometabolic complications are well acknowledged.

\section{Acknowledgement}

We wish to thank Cláudia Nascimento Montemor (M.D., Endocrinologist, PhD Student) for the discussing the first draft of this manuscript and the endocrinology residents Ubirajara Cunha de Aguiar, Mayara Volpi e Silva and Lérida Russi Garcia for the bibliography search.

\section{References}

1. Whaley Connell A, Johnson MS, Sowers JR (2010) Aldosterone: role in the cardiometabolic syndrome and resistant hypertension. Prog Cardiovasc Dis 52(5): 401-409.

2. Fischer E, Adolf C, Pallauf A, Then C, Bidlingmaier M, et al. (2013) Aldosterone excess impairs first phase insulin secretion in primary aldosteronism. J Clin Endocrinol Metab 98(6): 2513-2520.

3. Funder JW, Carey RM, Mantero F, Murad MH, Reincke M, et al. (2016) The management of primary aldosteronism: case detection, diagnosis, and treatment: an endocrine society clinical practice guideline. The Journal of Clinical Endocrinology \& Metabolism 101(5): 1889-1916.

4. Mulatero P, Monticone S, Veglio F (2011) Diagnosis and treatment of primary aldosteronism. Reviews Rev Endocr Metab Disord 12(1): 3-9.

5. Mazzuco TL, Grunenwald S, Lampron A, Bourdeau I, Lacroix A (2010) Aberrant hormone receptors in primary aldosteronism. Horm Metab Res 42(6): 416-423.

6. Sabbadin C, Fallo F (2016) Hyperaldosteronism: screening and diagnostic tests. High Blood Press Cardiovasc Prev 23(2): 69-72.

7. Burrello J, Monticone S, Buffolo F, Tetti M, Giraudo G, et al. (2015) Issues in the diagnosis and treatment of primary aldosteronism. High Blood Pressure \& Cardiovascular Prevention 23(2): 73-82.

8. Crudo V, Monticone S, Burrello J, Buffolo F, Tetti M, et al. (2016) Hyperaldosteronism: how to discriminate among different disease forms? High Blood Press Cardiovasc Prev 23(3): 203-208.

9. El Ghorayeb N, Mazzuco TL, Bourdeau I, Mailhot JP, Zhu PS, et al. (2016) Basal and post-ACTH aldosterone and its ratios are useful during adrenal vein sampling in primary aldosteronism. J Clin Endocrinol Metab 101(4): 1826-1835.

10. Briones AM, Nguyen Dinh Cat A, Callera GE, Yogi A, Burger D, et al. (2012) Adipocytes produce aldosterone through calcineurindependent signaling pathways: implications in diabetes mellitus- 


\section{Current Research in Diabetes \& Obesity Journal}

associated obesity and vascular dysfunction. Hypertension 59(5): 1069-1078.

11. Zavatta G, Casadio E, Rinaldi E, Pagotto U, Pasquali R, et al. (2016) Aldosterone and type 2 diabetes mellitus. Horm Mol Biol Clin Investig 26(1): 53-59.

12. Huby AC, Antonova G, Groenendyk J, Gomez-Sanchez CE, Bollag WB, et al. (2015) Adipocyte-derived hormone leptin is a direct regulator of aldosterone secretion, which promotes endothelial dysfunction and cardiac fibrosis. Circulation 132(22): 2134-2145.

13. Tirosh A, Hannah Shmouni F, Lyssikatos C, Belyavskaya E, Zilbermint M, et al. (2017) Obesity and the diagnostic accuracy for primary aldosteronism. J Clin Hypertens (Greenwich) 19(8): 790-797.

14. Bochud M, Nussberger J, Bovet P, Maillard MR, Elston RC, et al. (2006) Plasma aldosterone is independently associated with the metabolic syndrome. Hypertension 48(2): 239-245.

15. Di Murro A, Petramala L, Cotesta D, Zinnamosca L, Crescenzi E, et al (2010) Renin-angiotensin-aldosterone system in patients with sleep apnea: prevalence of primary aldosteronism. J Renin Angiotensin Aldosterone Syst 11(3): 165-172.

16. Johnson S (2018) Screening for obstructive sleep apnea is imperative for diabetes mellitus patients. Curre Res Diabetes \& Obes J 5(5): 555674 .
17. Tuomilehto HJ, Seppä M Uusitupa (2013) Obesity and obstructive sleep apnea -Clinical significance of weight loss. Sleep Medicine Reviews 17(5): 321-329.

18. PrattUbunama MN, Nishizaka MK, Boedefeld RL, Cofield SS, Harding SM, et al. (2007) Plasma aldosterone is related to severity of obstructive sleep apnea in subjects with resistant hypertension. Chest 131(2): 453-459.

19. Giacchetti G, Sechi LA, Rilli S, Carey RM (2005) The renin-angiotensinaldosterone system, glucose metabolism and diabetes. Trends Endocrinol Metab 16(3): 120-126.

20. Fallo F, Veglio F, Bertello C, Sonino N, Della Mea P, et al. (2006) Prevalence and characteristics of the metabolic syndrome in primary aldosteronism. J Clin Endocrinol Metab 91(2): 454-459.

21. Reincke M, Meisinger C, Holle R, Quinkler M, Hahner S, et al. (2010) Is primary aldosteronism associated with diabetes mellitus? Results of the German Conn's Registry. Horm Metab Res 42(6): 435-439.

22. Stiefel P, Vallejo Vaz AJ, García Morillo S, Villar J (2011) Role of the reninangiotensin system and aldosterone on cardiometabolic syndrome. Int J Hypertens 2011: 685238.

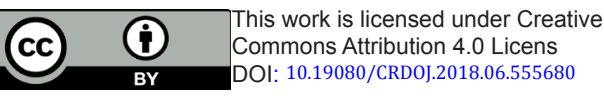

\section{Your next submission with Juniper Publishers will reach you the below assets}

- Quality Editorial service

- Swift Peer Review

- Reprints availability

- E-prints Service

- Manuscript Podcast for convenient understanding

- Global attainment for your research

- Manuscript accessibility in different formats

( Pdf, E-pub, Full Text, Audio)

- Unceasing customer service

Track the below URL for one-step submission https://juniperpublishers.com/online-submission.php 